ZOOLOGIA 29 (2): 167-171, April, 2012

doi: $10.1590 /$ S1984-46702012000200009

\title{
Setting the reference for the use of Chironomus sancticaroli (Diptera: Chironomidae) as bioindicator: Ontogenetic pattern of larval head structures
}

\author{
Débora Rebechi ${ }^{1} \&$ Mário Antônio Navarro-Silva ${ }^{1,2}$
}

${ }^{1}$ Laboratório de Entomologia Médica e Veterinária, Departamento de Zoologia, Setor de Ciências Biológicas, Universidade Federal do Paraná. Caixa Postal 19020, 81531-980 Curitiba, PR, Brazil.

2 Corresponding author. E-mail: mnavarro@ufpr.br

\begin{abstract}
Species of Chironomidae are widely used as bioindicators of water quality, since their larvae undergo morphological deformities when in contact with sediment contaminated with chemicals. In this work we endeavored to study the morphology of head structures (antennae, mandible, mentum, pecten epipharyngis, ventromental plate and premandible) throughout the development of the four larval instars of Chironomus sancticaroli Strixino \& Strixino, 1981, which can be used in environmental impact analyses. Our results show that it is possible to differentiate among larval instars by doing a quantitative analysis on the number of striae on the ventromental plates. The six structures analyzed changed during larval ontogeny. These changes are part of the ontogeny of the immature stages not exposed to xenobiotics. We believe that the morphological pattern defined in this work can be used for comparisons with ontogenetic changes observed in field studies conducted in polluted environments.
\end{abstract}

KEY WORDS. Bioindicator; larva; mosquito; morphology.

Given the ecological importance of the Chironomidae in the dynamics of aquatic ecosystems, they were often used as bioindicators in studies monitoring water quality (CoRTELEzzi et al. 2011). Morphological changes in the immature forms can be used to ascertain the environmental impacts of chemical pollutants (Kwak \& Lee 2005, Di Veroli et al. 2010, Park et al. 2010). Deformities were found mainly in the structures of the larval head capsule, such as antennae (BHATTACHARYAY et al. 2005), mandible (Vermeulen et al. 2000a), mentum (NazArova et al. 2004), pecten epipharyngis (WaTTs et al. 2003), and premandible (Janssens de Bisthoven et al. 2005). In the characterization of the deformities the cited authors used information from other studies, which indicates the types of deformities or a normal morphology for a given species.

The larval development of most chironomid species usually includes four larval instars. Larvae in different populations may present various degrees of morphological deformities in different frequencies (Martinez et al. 2002, Di Veroli et al. 2008).

The larva, pupa, adult male and female of Chironomus sancticaroli Strixino \& Strixino, 1981 have all been previously described by Strixino \& Strixino (1981). The description of the larval stage, based on the fourth instar larva, comprised the mandible, mentum and pecten epipharyngis. The species, distributed in Argentina and Brazil, has been used in environmental impact analyses as a bioindicator (e.g., PRINTes et al. 2011). In this study we endeavored to describe the morphol- ogy of the antenna, mandible, mentum, pecten epipharyngis, ventromental plate and premandible of the first, second, third, and fourth instar larvae of $C$. sancticaroli. This study is based on individuals not impacted by xenobiotics in order to produce reference data that can be compared with results from specimens employed in studies of bioindicators.

\section{MATERIAL AND METHODS}

We obtained the studied specimens from a breeding colony at the Laboratory of Medical and Veterinary Entomology, Universidade Federal do Paraná (UFPR). This colony had been established approximately two years before (more than 20 generations in the laboratory) and was maintained following the protocol of MaIER et al. (1990), with modifications in the temperature $\left(25^{\circ} \mathrm{C} \pm 2\right)$ and photoperiod $(12 \mathrm{~h}$ light: $12 \mathrm{~h}$ dark). We analyzed the head of a total of 1,108 larvae, from the first to fourth larval instars (Tab. I), fixed and stored in $70 \%$ alcohol. The larvae were placed in potassium hydroxide $(\mathrm{KOH})$ $6 \%$ at $50^{\circ} \mathrm{C}$. Larvae from first, second, third, and fourth instars, were diaphanized, respectively, for 30 minutes, 2, 4 and 6 hours. After clearing, the larvae were placed on slides with their ventral sides up, in a semi-permanent solution containing glycerin and absolute alcohol 3:1, and sealed with enamel.

We analyzed the head structures (antennae, mandible, mentum, pecten epipharyngis, ventromental plate and 
premandible) under a microscope. A camera lucida was used for making the illustrations. We used the terminology of SAETHER (1980) to describe and discuss the structures (Figs 1-7).

\section{RESULTS}

The antenna is composed by a basal segment, a flagellum with four articles, the antennal blade, the accessory blade, and the ring organ. These components do not change throughout larval development, except for the absence of the ring organ in the first instar larva. However, the first instar larva differs from larvae in other instars by the exceptionally short and flat basal segment and the disproportionately long antennal blade (Figs 8-11).

The mandibles in the third and fourth instars have five teeth (four ventral and one dorsal), thorns, striae, ring organ, mola, internal seta, seta subdentalis, and pecten mandibularis. They have a triangular shape and a long apical tooth. The following structures are absent from first instar larvae: internal seta, pecten mandibularis, striae, and ring organ. Second instar larvae lack the striae and the ring organ, but the pecten mandibularis and internal seta are well developed (Figs 12-15).
The pecten epipharyngis is absent in first instar larvae and the morphological pattern of the teeth changes during the ontogenetic development in size and number of teeth, which vary as follows: second instar: 9-11, third instar: 11-13, fourth instar: 14-17 (Figs 16-18).

The number of striae on the ventromental plates changed during larval development and was not possible to quantify these striae in the first instar. They vary as follows: second instar 12-16; third instar 20-24; fourth instar 36-40. This structure allows us to clearly define and separate the larval instars of C. sancticaroli (Figs 19-22).

The premandibles are bifid and have a premandibular brush. This morphological pattern did not change throughout the development (Figs 23-26).

The mentum has 13 teeth, six on each side (called laterals) and a central trifid tooth. The coloration and dimensions of the teeth vary throughout larval development. In the first instar larva the teeth are generally narrow and long, with elongate tips, and the central trifid tooth is longer than the others. In the second instar larva the teeth become proportionally wider and the central trifid tooth and the two laterals teeth have the

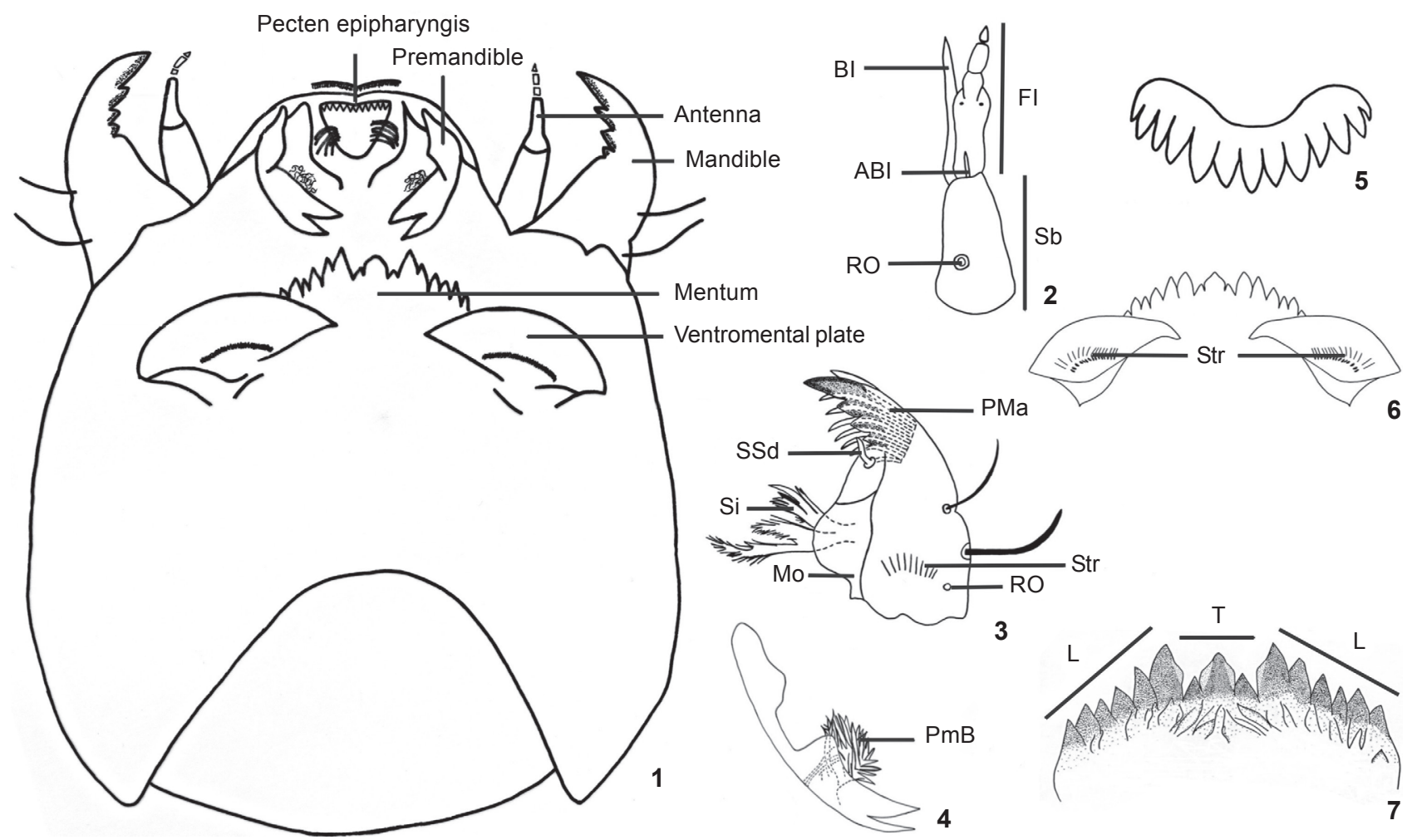

Figures 1-7. Ventral view of the cephalic capsule of Chironomus sancticaroli showing the structures selected for morphological analysis; (2) right antenna; (3) right mandible; (4) premandible; (5) pecten epipharyngis; (6) ventromental plate; (7) mentum. ABI: accessory blade, BI: blade, Fl: antennal flagellum, L: lateral teeth, Mo: mola, PMa: pecten mandibularis, PmB: premandibular brush, RO: ring organ, Sb: basal segment, Si: internal seta, SSd: seta subdentalis, Str: striae, T: trifid central tooth. 

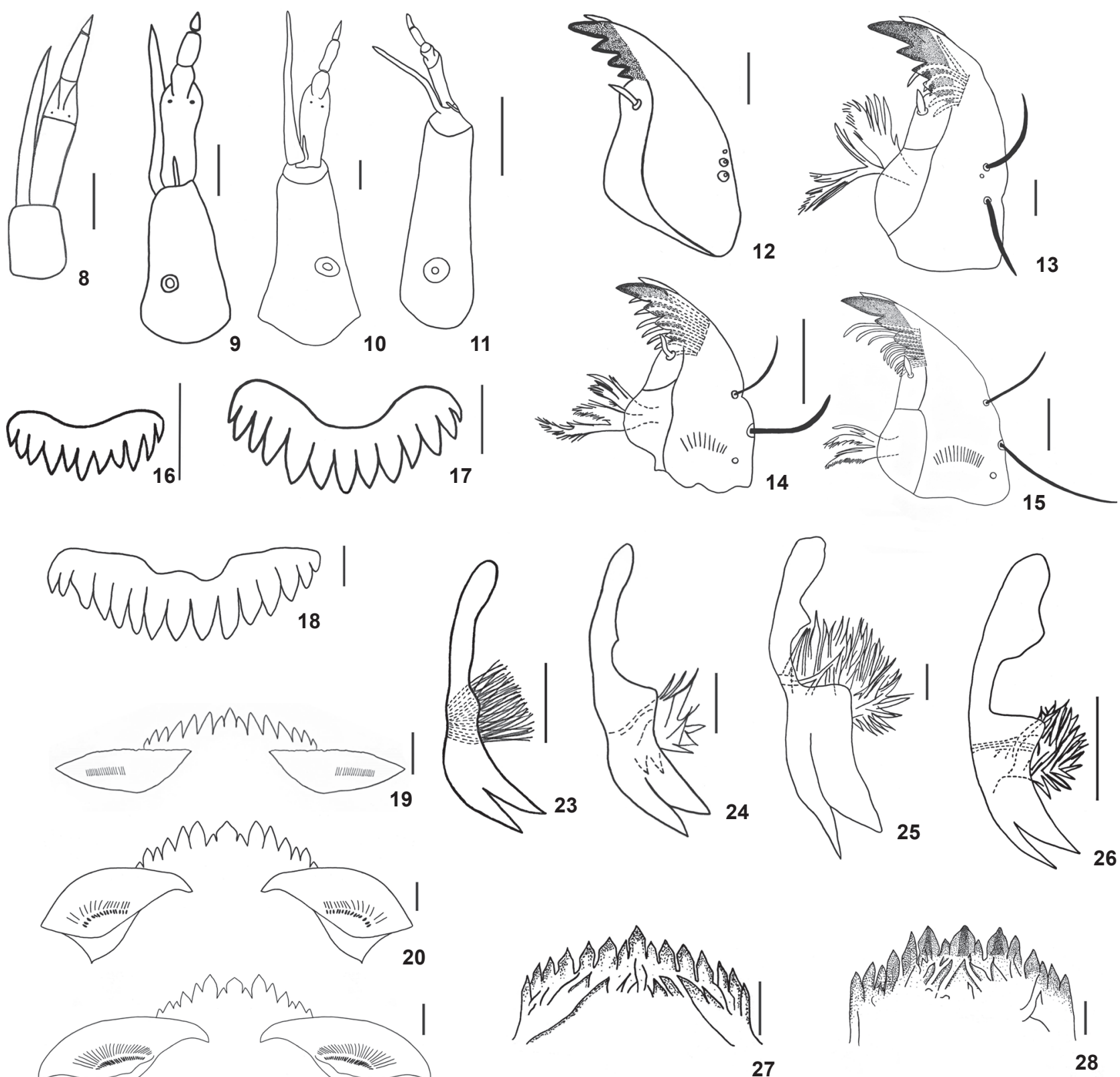

21
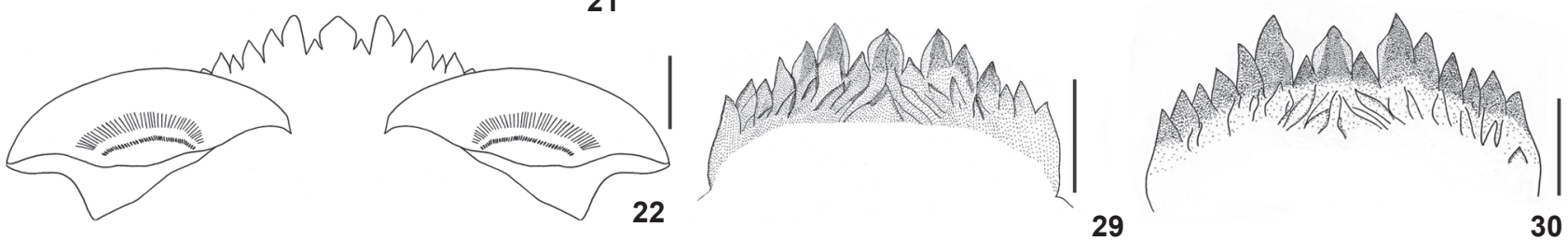

Figures 8-30. Chironomus sancticaroli. Morphological pattern of the: (8-11) antennae of first to fourth instar, respectively; (12-15) mandible of first to fourth instar, respectively; (16-18) pecten epipharyngis of second to fourth instar, respectively; (19-22) ventromental plate of first to fourth instar, respectively; (23-26) premandible of first to fourth instar, respectively; (27-30) mentum of first to fourth instar, respectively. Scale bars: 8-13, 19-21, 23-25, 27, $28=0.01 \mathrm{~mm} ; 14,15,22,26,29,30=0.05 \mathrm{~mm}$. 
Table I. Cephalic structures and number of heads studied for each larval instar of Chironomus sancticaroli. (N) Normal, (A) morphological alteration.

\begin{tabular}{|c|c|c|c|c|c|c|c|c|c|}
\hline \multirow{3}{*}{ Structures } & \multicolumn{8}{|c|}{ Instars } & \multirow{3}{*}{ Total } \\
\hline & \multicolumn{2}{|c|}{1} & \multicolumn{2}{|c|}{ II } & \multicolumn{2}{|c|}{ III } & \multicolumn{2}{|c|}{ IV } & \\
\hline & $\mathrm{N}$ & A & $\mathrm{N}$ & A & $\mathrm{N}$ & A & $\mathrm{N}$ & A & \\
\hline Antennae & 38 & 0 & 36 & 0 & 49 & 0 & 63 & 0 & 186 \\
\hline Mandibles & 39 & 0 & 36 & 0 & 49 & 0 & 61 & 0 & 185 \\
\hline Mentum & 39 & 0 & 33 & 3 & 33 & 16 & 62 & 0 & 186 \\
\hline Pecten epipharyngis & 39 & 0 & 32 & 0 & 48 & 0 & 74 & 0 & 193 \\
\hline Ventromental plates & 38 & 0 & 36 & 0 & 47 & 0 & 62 & 0 & 183 \\
\hline Premandibles & 34 & 0 & 34 & 0 & 44 & 0 & 63 & 0 & 175 \\
\hline Total & 227 & 0 & 207 & 3 & 270 & 16 & 385 & 0 & 1108 \\
\hline
\end{tabular}

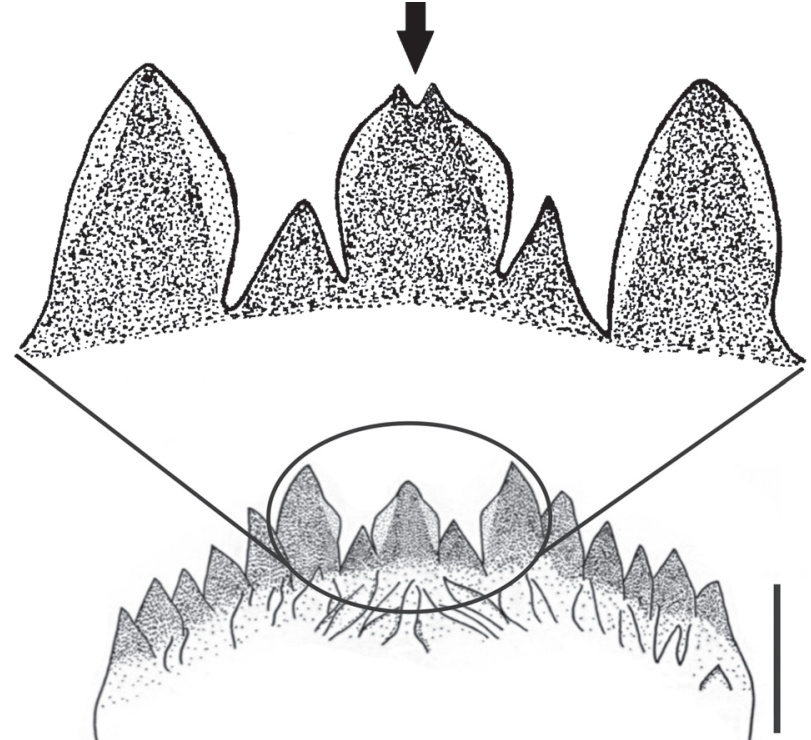

Figure 31. Morphological alteration (split) observed in the mentum of second and third instar larvae of Chironomus sancticaroli.

same size. It is possible to note, at this stage, that the fourth lateral tooth (counting the central trifid as the first) is slightly smaller than the third and fifth teeth. In the third and fourth instars, the central trifid tooth is smaller than the first lateral pair and the fourth pair is smaller than the third and the first teeth (Figs 27-30). The mental central trifid tooth has a peculiar and differentiated pattern (split) in $8.3 \%(n=3)$ of the second instar larvae and in $32.6 \%(n=16)$ of the third instar larvae (Tab. I, Fig. 31).

\section{DISCUSSION}

The split in the central trifid tooth has been considered as a morphological deformity in Chironomus riparius Meigen, 1804 exposed to cadmium for nine generations (JANSSENS DE
Bisthoven et al. 2001) and in larvae of Chironomus tentans Fabricius, 1805 reared for more than one year (BIRD 1997) or exposed to zinc and lead (Martinez et al. 2001). As C. sancticaroli individuals used in our morphological analysis did not come into contact with chemical pollutants, we cannot draw a connection between the division of the central tooth and chemical exposure. However, since our experimental population was maintained under laboratory conditions for about two years, we cannot rule out the possibility of inbreeding, which has been reported also as a possible cause of high levels of deformities in cultured chironomids (BIRD et al. 1995, BIRD 1997, Vermeulen et al. 2000a, DiAs et al. 2008).

In aquatic ecosystems, fourth instar larvae spend more time in contact with chemical pollutants, for this reason they are most often collected for morphological analysis to ascertain environmental impact (Vermeulen et al. 2000b, Di Veroli et al. 2008). Since other larval instars can be commonly collected (DickMan et al. 1992), it is important to check if the particularity found in the central trifid tooth of second and third instar larvae stem from inbreeding or corresponds to an intrinsic feature of this population and, consequently, cannot be used as an indication of the presence of xenobiotics.

Environmental analyses of $C$. sancticaroli to ascertain contamination by xenobiotics using morphological deformities in the larvae can be performed with all the structures mentioned in this study. However, the correct identification of larval instars is extremely important, since only changes promoted by physiological age are visible in the morphology of organisms. Therefore, our description complements the literature data on the species and provides a reference material for comparisons with field samples.

\section{ACKNOWLEDGMENTS}

We thank Conselho Nacional de Desenvolvimento Científico e Tecnológico (CNPq, process 305038/2009-5); Caroline N.S. de Oliveira for her assistance preparing the plates; Vinicius Richardi for his help maintaining the chironomid colony. 


\section{LITERATURE CITED}

Bhattacharyay, G.; A.K. Sadhu; A. Mazumdar \& P.K. Chaudhuri. 2005. Antennal deformities of chironomid larvae and their use in biomonitoring of heavy metal pollutants in the river Damodar of west Bengal, India. Environmental Monitoring and Assessment 108 (1-3): 67-84.

Bird, G.A. 1997. Deformities in cultured Chironomus tentans larvae and the influence of substrate on growth, survival and mentum wear. Environmental Monitoring and Assessment 45 (3): 273-283.

Bird, G.A.; M.J. Rosentreter \& W.J. Schwartz. 1995. Deformities in the menta of chironomid larvae from the Experimental Lakes Area, Ontario. Canadian Journal of Fisheries and Aquatic Sciences 52 (10): 2290-2295.

Cortelezzi, A.; A.C. Paggi; M. Rodríguez \& A. Rodrigues Capítulo. 2011. Taxonomic and nontaxonomic responses to ecological changes in an urban lowland stream through the use of Chironomidae (Diptera) larvae. Science of the Total Environment 409 (7): 1344-1350.

Di Veroli, A.; E. Goretti; C. Marcucci; A. Fabrizi; L. Scopetta \& M.V. Di Giovanni. 2008. Incidence of larvae mouthpart deformities in Chironomus plumosus (Diptera: Chironomidae) and Procladius sp. (Diptera: Chironomidae) from Piediluco Lake, Italy. Boletim do Museu Minicipal do Funchal 13: 13-20.

Di Veroli, A.; R. Selvaggi; R.M. Pellegrino \& E. Goretti. 2010. Sediment toxicity and deformities of chironomid larvae in Lake Piediluco (Central Italy). Chemosphere 79 (1): 33-39.

Dias, V.; C. Vasseur \& J.-M. Bonzom. 2008. Exposure of Chironomus riparius larvae to uranium: Effects on survival, development time, growth, and mouthpart deformities. Chemosphere 71 (3): 574-581.

DickMAn, M.; I. BRINDLE \& M. Benson. 1992. Evidence of teratogens in sediments of the Niagara River watershed as reflected by Chironomid (Diptera: Chironomidae) deformities. Journal of Great Lakes Research 18 (3): 467-480.

Janssens de Bisthoven, L.; J. Postma; A. Vermeulen; G. Goemans \& F. OlLevier. 2001. Morphological deformities in Chironomus riparius Meigen larvae after exposure to cadmium over several generations. Water, Air, and Soil Pollution 129 (14): 167-179.

Janssens de Bisthoven, L.; A. Gerhardt \& A.V.M.V. Soares. 2005. Chironomidae larvae as bioindicators of an acid mine drainage in Portugal. Hydrobiologia 532 (1-3): 181-191.

KWAK, I.-S. \& W. LEe. 2005. Mouthpart deformity and developmental retardation exposure of Chironomus plumosus (Diptera:
Chironomidae) to tebufenozide. Bulletin of Environmental Contamination and Toxicology 75 (5): 859-865.

Maier, K.J.; P. Kosalwat \& A.W. Knight. 1990. Culture of Chironomus decorus (Diptera: Chironomidae) and the effect of temperature on its life history. Environmental Entomology 19 (6): 1681-1688.

Martinez, E.A.; B.C. Moore; J. Schaumloffel \& N. Dasgupta. 2001. Induction of morphological deformities in Chironomus tentans exposed to zinc- and lead-spiked sediments. Environmental Toxicology 20 (11): 2475-2481.

Martinez, E.A.; B.C. Moore; J. Schaumloffel \& N. Dasgupta. 2002. The potential association between menta deformities and trace elements in Chironomidae (Diptera) taken from a heavy metal contaminated river. Archives of Environmental Contamination and Toxicology 42 (3): 286-291.

NAZARova, L.B.; H.W. Riss \& A. KAHLHEBER. 2004. Some observation of buccal deformities in chironomid larvae (Diptera: Chironomidae) from the Ciénaga Grande de Santa Marta, Colombia. Caldasia 26 (1): 275-290.

PARK, K.; J. PARK; J. Kim \& I.-S. KwaK. 2010. Biological and molecular responses of Chironomus riparius (Diptera: Chironomidae) to herbicide 2,4-D (2,4-dichlorophenoxyacetic acid). Comparative Biochemistry and Physiology, Part C 151 (4): 439-446.

Printes, L.B.; M.N. Fernandes \& E.L.G. Espíndola. 2011. Laboratory measurements of biomarkers and individual performances in Chironomus xanthus to evaluate pesticide contamination of sediments in a river of southeastern Brazil. Ecotoxicology and Environmental Safety 74 (3): 424-430.

SAETHER, O.A. 1980. Glossary of chironomid morphology terminology (Diptera: Chironomidae). Entomologica Scandinavica Suplements 14: 1-51.

Strixino, S.T. \& G. Strixino. 1981. Nova espécie do gênero Chironomus Meigen do sul do Brasil (Diptera: Chironomidae). Revista Brasileira de Entomologia 25 (4): 333-340.

Vermeulen, A.C.; G. Liberloo; P. Dumont; F. Ollevier \& B. Goddeeris. 2000a. Exposure of Chironomus riparius larvae (Diptera) to lead, mercury and ${ }^{2}$-sitosterol: effects on mouthpart deformation and moulting. Chemosphere 41 (10): 1581-1591.

Vermeulen, A.C.; G. Liberloo; F. Ollevier \& B. Goddeeris. 2000 b. Ontogenesis, transfer and repair of mouthpart deformities during moulting in Chironomus riparius (Diptera: Chironomidae). Archiv für Hydrobiologie 147 (3): 401-415.

Watts, M.M.; D. Pascoe \& K. Carroll. 2003. Exposure to 17士ethinylestradiol and bisphenol Aeffects on larval moulting and mouthpart structure of Chironomus riparius. Ecotoxicology and Environmental Safety 54 (2): 207-215.

Submitted: 22.XI.2011; Accepted: 05.IV.2012.

Editorial responsibility: Gabriel L.F. Mejdalani 